\title{
MECHANISMS OF DISEASE Novel Therapies Based on Mechanisms of HIV-1 Cell Entry
}

\author{
J. Michael Kilby, M.D., and Joseph J. Eron, M.D.
}

From the Department of Medicine, University of Alabama, Birmingham (J.M.K.); and the Department of Medicine, University of North Carolina, Chapel Hill (J.J.E.). Address reprint requests to Dr. Kilby at 908 20th St. S., UAB, Birmingham, AL 35294-2050, or at mkilby@uab.edu.

N EngIJ Med 2003;348:2228-38. Copyright $\odot 2003$ Massachusetts Medical Society.

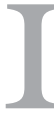
NFECTION WITH HUMAN IMMUNODEFICIENCY VIRUS TYPE 1 (HIV-1), THE retrovirus that causes the acquired immunodeficiency syndrome (AIDS), is one of the leading causes of death worldwide. All currently available antiretroviral agents inhibit essential HIV-1 enzymes - either the reverse transcriptase or the protease (Fig. 1). Recent advances have markedly improved the outcome for many patients who receive these classes of antiretroviral drugs. However, the success of current therapy is limited by the emergence of drug-resistant viruses, the necessity of sustained adherence to complex regimens, and the potential for toxic effects. Novel classes of safe and effective agents with a low risk of cross-resistance with other antiretroviral drugs are needed.

Targeting viral entry may have advantages over the inhibition of steps in the viral life cycle after the cell has been infected. A better understanding of how HIV-1 binds to and enters cells has prompted a reappraisal of previous attempts to block viral entry and an evaluation of new approaches (Table 1). In this article, we outline the steps involved in viral attachment and entry, provide an update on agents under development that have been designed to inhibit each of these steps, and consider the prospects of these compounds in the treatment of human immunodeficiency virus (HIV) infection.

HIV-1 BIN DING AND ENTRY

EARLY CHARACTERIZATION OF THE VIRAL ENVELOPE AND CD4+ T-CELL TROPISM

The initial characterization of HIV-1 centered on its tropism for mature human helper T lymphocytes, which express the CD4 (or T4) surface protein (also expressed on monocytes, dendritic cells, and brain microglia). ${ }^{1-4}$ Molecular studies demonstrated that, like other retroviruses, the HIV-1 particle is surrounded by a lipid bilayer, derived from the host cell and studded with viral glycoproteins (Fig. 2). The infectivity of HIV requires the surface glycoprotein subunit (gp120) and the transmembrane glycoprotein subunit (gp41) of gp160, a viral precursor protein. The two subunits are cleaved from gp160 by host-cell proteases and then reassembled as oligomeric structures (trimers) on the viral membrane (Fig. 3A).5,6

The amino acid sequence of gp120 contains five variable regions (V1 through V5), alternating with more conserved regions; the variable regions tend to be exposed on the viral surface. ${ }^{7,8}$ Noncontiguous regions of the gp120 molecule come together to form the CD4 binding site, and small deletions or substitutions in either CD4 or conserved regions of gp120 disrupt the binding of the virus. 9-11

The design of inhibitors of viral entry must take into account the three-dimensional structure and the variability in the sequence of the intact wild-type HIV-1 envelope, rather than the linear sequences of denatured proteins or the envelopes of laboratory-adapted strains of HIV-1, which do not reliably predict the in vivo activity of investigational agents that block viral entry. 


\section{THE SEARCH FOR ENTRY COFACTORS}

Because CD4 alone is insufficient to permit the entry of HIV-1, it has long been suspected that additional receptors or other factors are required. Although most HIV-1 isolates successfully infect primary helper $\mathrm{T}$ cells, individual viral isolates have a range of tropisms (for example, in vitro, some preferentially infect macrophages over T-cell lines) and cause varying degrees of cell fusion (formation of syncytia or multinucleated giant cells) in T-cell lines. Amino acid residues within conserved V3-loop sites of gp120 were known to affect membrane fusion, ${ }^{12,13}$ but the basis of the differences in tropism was until recently poorly understood. Important clues to the "coreceptor" mystery arose from the discovery that $\beta$-chemokines (macrophage inflammatory proteins $1 \alpha$ and $1 \beta$ [MIP- $1 \alpha$ and MIP- $1 \beta$ ], as well as RANTES [regulated upon activation normal T-cell expressed and secreted]), which are chemotactic cytokines produced by macrophages, activated T cells, and natural killer cells, suppress the replication of some strains of HIV-1. ${ }^{14}$

\section{CHEMOKINE CORECEPTORS (CC CHEMOKINE RECEPTOR 5 AND CXC CHEMOKINE RECEPTOR 4)}

After the seminal discovery by Feng and colleagues that a G-protein-coupled chemokine receptor, CXC chemokine receptor 4 (CXCR4), was the key to cellular entry for viruses that grow well in cultured T-cell lines (X4 viruses), ${ }^{15}$ several groups of researchers rapidly confirmed that chemokine receptors were the missing link in our understanding of HIV-1 entry (Fig. 2). The expression of CXCR4 made otherwise impenetrable CD4+ cell lines susceptible to productive HIV-1 infection. CC chemokine receptor 5 (CCR5), a $\beta$-chemokine receptor with a seventransmembrane-protein structure similar to that of CXCR4, was found to serve as a coreceptor for nonsyncytium-inducing or macrophage-tropic HIV-1 ( $\mathrm{R} 5$ viruses). ${ }^{16,17}$ Chemokine receptors are the primary binding sites for many related retroviruses, and HIV-1 can be genetically modified to allow CD4independent cell entry, ${ }^{18}$ suggesting that CXCR 4 and CCR 5 are the primordial receptors, rather than just cofactors. ${ }^{19}$

HIV-1 isolates of the R5 type have been implicated in most cases of sexually transmitted HIV infection, whereas $\mathrm{X} 4$ viruses, which replicate best in T-cell lines, often predominate in the later stages of HIV disease and may be associated with rapid progression to AIDS and death. ${ }^{20,21}$ Clinical isolates may contain mixtures of $\mathrm{R} 5$ and $\mathrm{X} 4$ viruses, and

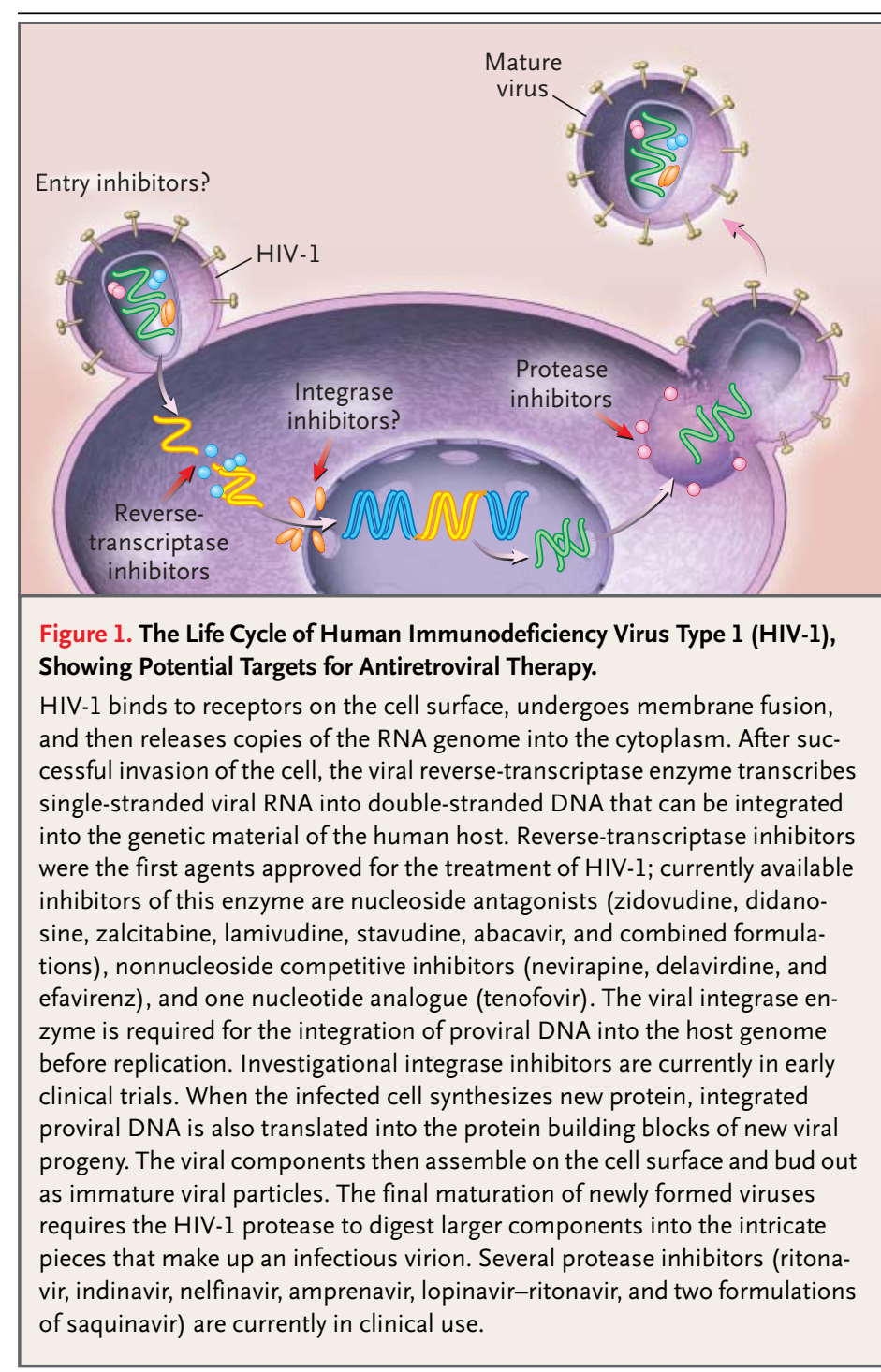

some individual viral strains (R5X4, or dual-tropic viruses) can use either the CXCR4 (X4-virus) or CCR5 (R5-virus) receptor. ${ }^{22}$ As previous experiments have suggested, V3-loop amino acid sequences in gp120 are major determinants of chemokinereceptor affinity. ${ }^{23,24}$ Although other chemokine receptors (CC chemokine receptors 2,3 , and 8 , $\mathrm{BOB}$, and others) can facilitate the entry of specific HIV-1 variants in vitro, all clinical isolates of HIV-1 use CCR5, CXCR4, or both for entry. ${ }^{25}$

Naturally occurring host defects in CCR 5 expression have demonstrated the clinical significance of these receptors. A homozygous deletion that prevents CCR 5 expression occurs disproportionately among persons who are frequently exposed to 


\begin{tabular}{|c|c|c|}
\hline Type of Inhibitor & Proposed Mechanism of Action & Developmental Status \\
\hline \multicolumn{3}{|l|}{ CD4-receptor inhibitors } \\
\hline Recombinant soluble CD4 & Competitively binds with gp 120 receptor & Limited activity in phase $1-2$ trials \\
\hline TNX-355 & $\begin{array}{l}\text { Monoclonal antibody against CD4, provides steric } \\
\text { hindrance for chemokine receptor binding }\end{array}$ & $\begin{array}{l}\text { Phase } 1-2 \text { (showing dose-related activity after a } \\
\text { single intravenous dose) }\end{array}$ \\
\hline PRO 542 & Tetrameric CD4 incorporated into gamma globulin & $\begin{array}{l}\text { Phase } 1-2 \text { (preliminary evidence of activity after } \\
\text { injections) }\end{array}$ \\
\hline BMS-806 & Binds to gp120 to block CD4 binding & Preclinical \\
\hline \multicolumn{3}{|c|}{ Chemokine-receptor inhibitors } \\
\hline $\mathrm{SCH}-\mathrm{C}$ & RANTES antagonist, competitively binds to CCR5 & $\begin{array}{l}\text { Phase } 1-2 \text { (showing short-term activity as oral } \\
\text { agent) }\end{array}$ \\
\hline PRO 140 & Monoclonal antibody against CCR5 & Preclinical \\
\hline AMD3100 & Bicyclam inhibitor of CXCR4 & $\begin{array}{l}\text { Minimal activity in most patients in phase } 2 \text { study } \\
\text { of intravenous administration }\end{array}$ \\
\hline \multicolumn{3}{|l|}{ Other attachment inhibitors } \\
\hline Dextran sulfate & $\begin{array}{l}\text { Possible charge-mediated attachment interference, } \\
\text { binds gp120 and inhibits CXCR4 interaction }\end{array}$ & $\begin{array}{l}\text { Phase } 1-2 \text { (showing mixed activity, excessive } \\
\text { toxicity) }\end{array}$ \\
\hline PRO 2000 & Binds to CD4 and interferes with gpl20 binding & Phase 2 in progress, as topical microbicide \\
\hline Cyanovirin- $\mathrm{N}$ & $\begin{array}{l}\text { Binds to gpl20, interferes with CD4 and CXCR4 } \\
\text { interactions }\end{array}$ & Preclinical, as topical microbicide \\
\hline \multicolumn{3}{|l|}{ Membrane-fusion inhibitors } \\
\hline Enfuvirtide (T-20) & Peptide that interferes with gp4l-mediated fusion & $\begin{array}{l}\text { Phase } 3 \text { (showing activity beyond } 1 \text { yr from subcuta- } \\
\text { neous injections, advantage at } 6 \text { mo as part of } \\
\text { salvage regimen); FDA approved for clinical use }\end{array}$ \\
\hline T-1249 & Peptide that interferes with gp4l-mediated fusion & $\begin{array}{l}\text { Phase 1-2 (showing short-term activity from subcu- } \\
\text { taneous injections, proof of concept to support } \\
\text { use as salvage treatment for patients with enfu- } \\
\text { virtide-resistant virus) }\end{array}$ \\
\hline "Five-helix" & $\begin{array}{l}\text { Binds to C terminal of gp } 41 \text { to form stable six-helix } \\
\text { structure, inhibits fusion }\end{array}$ & Preclinical \\
\hline
\end{tabular}

* RANTES denotes regulated upon activation normal T-cell expressed and secreted, CCR5 CC chemokine receptor 5, gp glycoprotein, and CXCR4 CXC chemokine receptor 4, and FDA Food and Drug Administration.

HIV-1 but who nonetheless remain uninfected. ${ }^{26}$ Heterozygous or partial mutation of a gene responsible for CCR5 expression on the cell surface does not block infection but does provide some protection from disease progression. ${ }^{27}$ Rare cases of infection in persons with a homozygous deletion of the gene responsible for CCR 5 expression appear to be caused by $\mathrm{X} 4$ viruses. ${ }^{28}$

\section{MEMBRANE FUSION}

The final step in viral entry, the fusion of the viral envelope with the cell membrane, is mediated by gp41. The molecular sequence of gp41 includes "heptad-repeat" regions (HR1 and HR2), reflecting the presence of periodic hydrophobic regions found in $\alpha$-helical "coiled-coil" structures. ${ }^{29,30}$ Mutations in the HR regions interfere with the fusion property of gp $41 . .^{31}$

A model of gp41-mediated membrane fusion analogous to the "spring-loaded" mechanism of influenzavirus has been proposed. After influenzavirus attaches to a target cell and enters the acid-rich endosome, the conformation of the hemagglutinin protein changes, shifting a "fusion peptide" into favorable position for the mediation of fusion. ${ }^{32}$ The model predicts that the gp120-gp41 trimer holds 


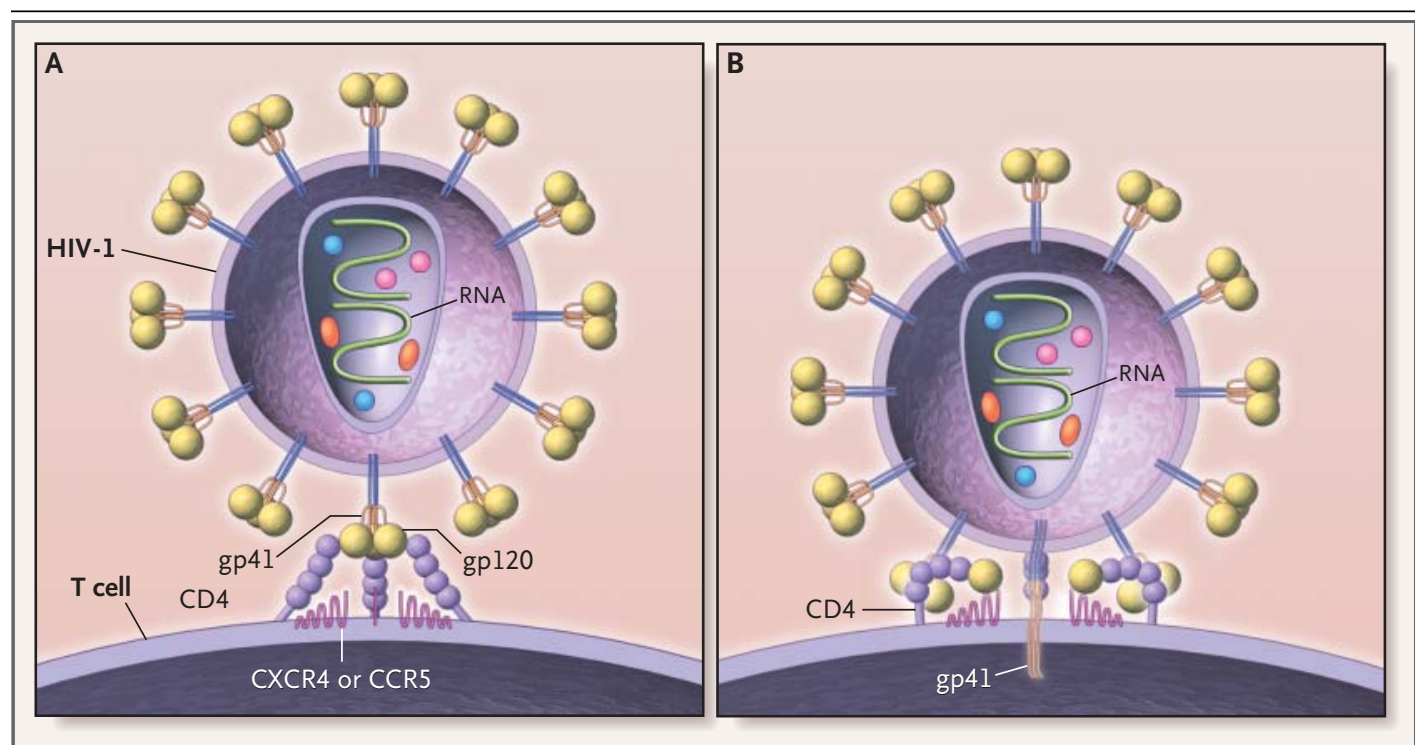

Figure 2. HIV-1-Binding Events and Potential Sites of Action for Various Viral-Entry Inhibitors.

HIV-l is covered by a lipid bilayer derived from host-cell membranes. Incorporated into this bilayer are viral glycoproteins as well as host adhesion molecules that may play a part in attachment to target cells. The viral-entry process consists of a series of coordinated interactions - binding to two different receptors (Panel A) and membrane fusion (Panel B). The viral envelope glycoproteins are synthesized as a single polyprotein that assembles into a trimer and then is broken down by host protease into surface glycoprotein subunits (gpl20) and transmembrane glycoprotein subunits (gp4l). Each gpl20 monomer is a complex, folded structure, consisting of a series of variable loops formed by disulfide bonds, with noncontiguous segments brought together to form three-dimensional binding sites for the CD4 receptor and a chemokine receptor (either CCR5 or CXCR4). Initial binding of gp120 to CD4 (Panel A) might be blocked by soluble CD4 decoys, monoclonal antibodies against sequences on gp 120 or CD4, or other small-molecular inhibitors. After CD4 binding, each gp120 undergoes a conformational change exposing the region that will bind to a seven-transmembrane chemokine receptor. Viral isolates have varying affinities for CCR5 or CXCR4 receptors. Binding of the chemokine coreceptors might be inhibited by natural ligands of these receptors or their derivatives, small-molecule inhibitors, monoclonal antibodies directed at the interacting sites, or down-regulation of receptor expression. It is hypothesized that binding of both the CD4 and chemokine receptors shifts away the steric hindrance of the heavily glycosylated gp120, allowing the gp4l segment to mediate membrane fusion and entry (Panel B).

each gp41 in a high-energy configuration, with the fusion peptide pointed inward, toward the viral surface (Fig. 3A). The binding of gp120 to CD4 and chemokine receptors is thought to release gp41 from this configuration, causing the fusion peptide to spring outward toward the cell membrane (Fig. 3B). Still in their trimeric association, the HR1 regions then fold over into the hydrophobic groove formed by the three corresponding HR2 regions, forming a stable six-helix bundle, thus bringing viral and cell membranes into proximity for fusion and entry (Fig. 3C). 33

\section{CRYSTALLIZING THE DYNAMIC ROLES OF THE VIRAL ENVELOPE PROTEINS}

Partial $\mathrm{x}$-ray crystallization of the HIV-1 glycoproteins, in complex with receptors, sheds light on the three-dimensional interactions between viral and host components during binding and entry. ${ }^{19}$ This imaging of the complexes has confirmed the sequential conformational changes that follow the binding of the virus to CD4 and chemokine receptors and has suggested the occurrence of several interdependent steps in the process of viral entry.

I NHIBITION OF VIRAL ENTRY

\section{INHIBITING THE INTERACTION OF GPI20} WITH THE CD4 MOLECULE

Initial attempts to block HIV entry focused on the interaction between gp 120 and CD4. Recombinant soluble CD4 (rsCD4), which was developed as a viral-attachment decoy, demonstrated potent inhibition of HIV-1 infection in vitro. ${ }^{34,35}$ In the clinical 


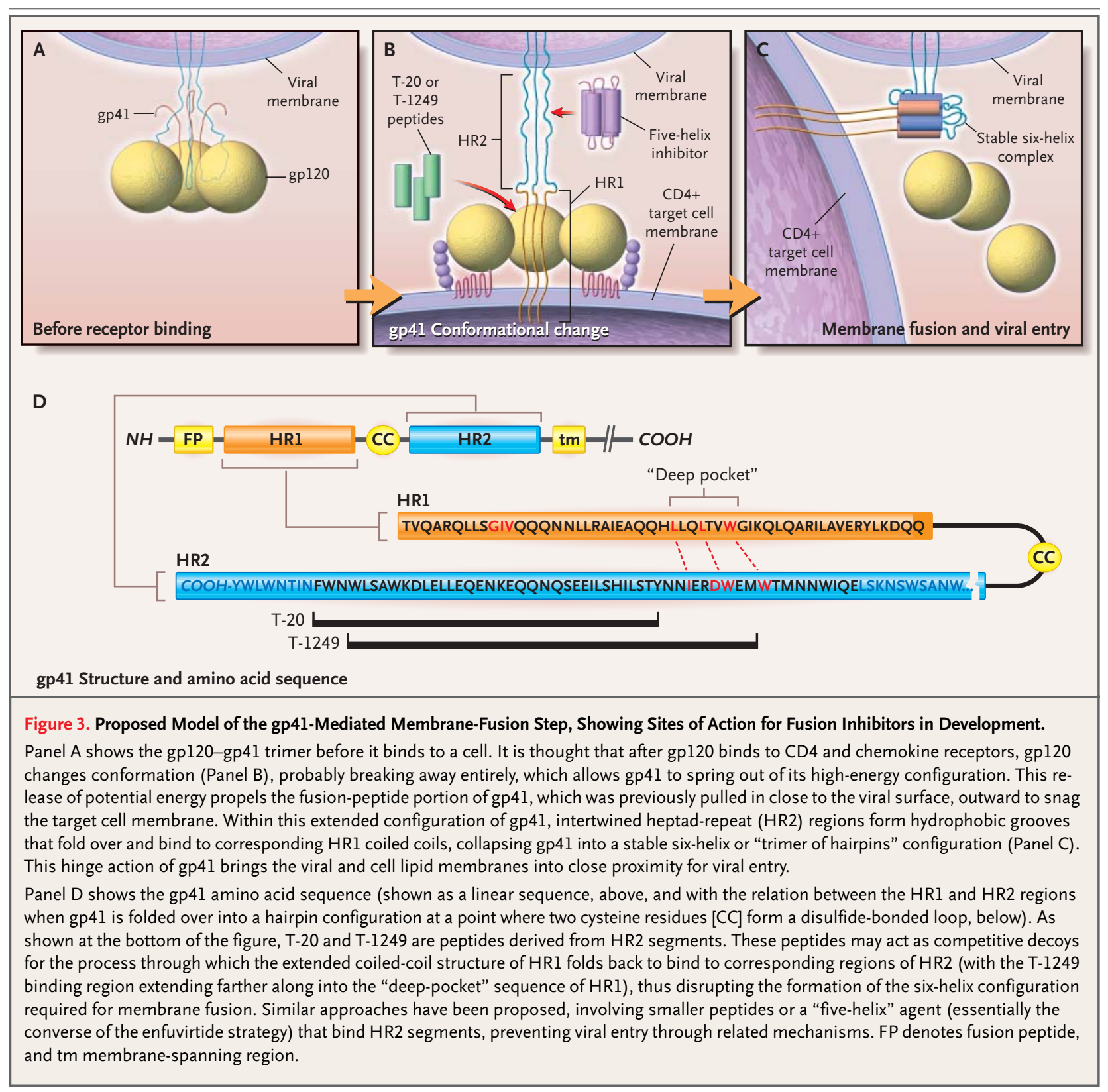

setting, however, rsCD4 had negligible activity except at very high doses. ${ }^{36-39}$ A chimeric molecule consisting of recombinant $\mathrm{CD} 4$ and gamma globulin had an extended half-life yet had little or no activity when administered with zidovudine. ${ }^{40}$ Despite these failures, new inhibitors of interactions between gp120 and CD4 continue to be pursued.

PRO 542, a hybrid tetramer, contains CD4 receptor domains within an IgG2 backbone and acts as a decoy for gp120 binding. It is active in vitro against diverse strains of HIV-1, including clinical iso- lates. ${ }^{41}$ PRO 542 must be administered parenterally but has a half-life in plasma of more than three days. In pilot studies, the compound was well tolerated and there was evidence of antiviral activity in adults ${ }^{42}$ and children. ${ }^{43}$

Monoclonal anti-CD4 antibodies can also block the interaction between gp120 and CD4; some of these monoclonal antibodies can inhibit the replication of multiple subtypes of HIV- 1 in vitro. ${ }^{44} \mathrm{Al}$ though anti-CD4 antibodies may have immunosuppressive effects, ${ }^{45,46}$ a recent report on a humanized 
anti-CD4 antibody called TNX-355 demonstrated no serious adverse events in the short term and no CD4-cell depletion. This dose-escalation trial showed clinically significant reductions in the viral load (of $>1.0 \log _{10}$ copies of HIV-1 RNA per milliliter) two to three weeks after a single intravenous dose of 10 to $25 \mathrm{mg}$ per kilogram of body weight. ${ }^{47}$

Certain small molecules may competitively and reversibly inhibit viral entry by binding gp120 and blocking the gp120-CD4 interaction. ${ }^{48} \mathrm{~A}$ lead compound of this type (BMS-806) demonstrated potent HIV-1 inhibition in vitro, but activity varied among different subtypes (clades) of HIV-1 and even within the same clade. Mutations in the region of gp120 that binds to CD4 cause resistance to BMS-806, supporting the proposed mechanism of action. ${ }^{49}$

\section{NONSPECIFIC INTERFERENCE} WITH ATTACHMENT

Dextran sulfate and other polyanions can inhibit the replication of HIV-1 in vitro. ${ }^{50}$ Originally attributed to nonspecific, charge-mediated interference with gp120-CD4 interactions, the effect of dextran sulfate has been linked more recently to its ability to attach to the V3 loop of X4 or R5X4 viruses, thus blocking the binding of gp120 to coreceptors. ${ }^{51,52}$ Dextran sulfate inhibits the replication of $\mathrm{X} 4$ isolates but may enhance $\mathrm{R} 5$ infections in vitro. ${ }^{53}$ Clinically, intravenous dextran sulfate was toxic and in some cases appeared to increase viral replication. ${ }^{54}$

PRO 2000 is a naphthalene polyanion that binds to $\mathrm{CD} 4$ but not to gp $120^{55}$; it is currently in clinical trials as a topical microbicide. ${ }^{56}$ Cyanovirin- $\mathrm{N}$, another topical compound with an active ingredient derived from blue-green algae, may interfere with several receptor-binding functions of gp120 simultaneously.57

\section{BLOCKING CHEMOKINE-RECEPTOR BINDING}

Several agents that bind the CCR 5 and CXCR 4 receptors and block HIV-1 replication in vitro are in development. ${ }^{14,58-61}$ CCR 5 may be a desirable target, because persons without CCR 5 expression on the surface of cells are relatively resistant to HIV-1 infection and have no obvious immunologic deficiencies. However, the role of CCR5 in inflammatory and immune responses is not fully understood and may vary in different clinical settings. Because $\mathrm{X} 4$ variants are linked with a rapid decline in the number ofCD4 cells, ${ }^{20,21}$ it is also potentially a concern that CCR 5 inhibitors may exert a selection pressure favoring CXCR4-tropic viruses.
The natural ligands for CCR 5 - the $\beta$-chemokines MIP 1- $\alpha$, MIP 1- $\beta$, and RANTES - inhibit HIV-1 replication in vitro. A series of small-molecule $\beta$-chemokine antagonists and monoclonal antibodies have potent in vitro activity (a 50 percent inhibitory concentration $\left[\mathrm{IC}_{50}\right]$ of less than $10 \mathrm{nM}$ ) against $\mathrm{R} 5$ variants, have no activity against $\mathrm{X} 4$ viruses, and act synergistically with approved antiretroviral drugs. ${ }^{62-65}$ Several compounds are now in clinical development. In a short-term pilot study, one such compound, $\mathrm{SCH}-\mathrm{C}$, reduced the mean plasma viral load by a factor of about three, although the effect varied from subject to subject. ${ }^{66}$ Selection of SCH-C-resistant HIV-1 in vitro has been observed without a switch from CCR 5 to CXCR 4 coreceptor usage. ${ }^{67}$

Because CXCR 4 occurs on a wider range of types of cells than CCR5, there is concern about potential adverse effects of blocking this receptor. Indeed, CXCR4-knockout mice have fatal congenital defects (including abnormal B-cell development and multiple malformations). ${ }^{68}$ Several CXCR 4 antagonists (cationic bicyclams) with in vitro activity have been developed, ${ }^{69-71}$ but it has been difficult to administer them, and their in vivo activity has been limited. One pilot study of a CXCR 4 antagonist involving 40 HIV-infected subjects demonstrated selective pressure against $X 4$ variants, but a response in the plasma viral load was observed in only one subject. ${ }^{72}$ Amino acid changes in gp120 (some in and around the V3 loop) that confer resistance to CXCR4 antagonists have been described. ${ }^{73}$ The $\alpha$-defensins, recently described endogenous HIV-1-inhibitory factors, are small cationic proteins that act predominantly against $\mathrm{X} 4$ variants ${ }^{74}$; at least part of this antiviral activity may be related to blocking the entry of the virus.

\section{BLOCKING THE FUSION OF VIRUS} WITH THE CELL MEMBRANE

Synthetic peptides that mimic HR2 segments of gp41 and probably block fusion by binding competitively to the hydrophobic groove formed by intertwined HR1 regions when gp41 is in its extended conformation (Fig. 3) have significant antiretroviral effects in vitro. ${ }^{29-31}$ Two peptides, T-20 and T-1249, are currently being studied in clinical trials. Several groups of investigators have demonstrated that other compounds in preclinical development smaller peptides as well as a "five-helix" protein ${ }^{75-77}$ - inhibit the replication of HIV-1 by related mechanisms. 


\section{T-20 (ENFUVIRTIDE)}

Enfuvirtide (T-20), a 36-amino-acid peptide derived from the HR2 sequence of a laboratory strain of HIV-1, has broad activity against X4, R5, and dualtropic variants of HIV-178 and is furthest along in clinical development. Oral treatment with this large peptide is not feasible. The initial clinical study of intravenous enfuvirtide monotherapy demonstrated potent antiretroviral effects without clinically significant short-term toxic effects. ${ }^{79}$ Further studies were undertaken to evaluate the use of enfuvirtide by subcutaneous injection. In a 28-day phase 2 study involving $78 \mathrm{HIV}$-infected adults in whom conventional regimens had failed, enfuvirtide was delivered by continuous subcutaneous infusion with the use of an insulin pump or by twice-daily subcutaneous injection. ${ }^{80}$ Dose-related decreases in the viral load were observed with both methods of administration, but continuous subcutaneous infusion was hampered by technical difficulties. The largest reductions in viral load (mean reduction, $1.6 \log _{10}$ copies of HIV-1 RNA per milliliter) were observed in the group that received twice-daily injections of $100 \mathrm{mg}$ of enfuvirtide. Viral-load rebound during therapy was noted in some subjects, and drug resistance was demonstrated in viruses from some of these subjects. ${ }^{81}$

Longer-term activity and tolerability appeared favorable in 70 subjects who had previously been involved in short-term clinical trials, who were then offered further open-label therapy with enfuvirtide (50 mg twice daily by subcutaneous injection). ${ }^{82} \mathrm{~A}$ randomized, open-label trial involving patients who had received protease inhibitors but had not had a clinical response to them suggested that switching to a salvage regimen containing a nonnucleoside reverse-transcriptase inhibitor plus enfuvirtide was more effective than the same salvage regimen without enfuvirtide. ${ }^{83}$ These results were similar to, or better than, those of other trials involving salvage regimens for subjects who had been treated with multiple antiretroviral regimens, but the limited size of these studies and their designs preclude definitive conclusions.

The results of two parallel phase 3 studies of enfuvirtide in patients with extensive previous treatment, one (T-20 vs. Optimized Regimen Only Study 1 [TORO 1] $)^{84}$ involving 491 subjects in North America and South America and the other (T-20 vs. Optimized Regimen Only Study 2 [TORO 2] $)^{85}$ involving 504 subjects in Europe and Australia, are published in this issue of the Journal. All participants underwent genotypic and phenotypic resistance testing to assist with the individualized selection of the best available antiretroviral regimen (the optimized background regimen), which consisted of three to five drugs, and then were randomly assigned in a 2:1 ratio to receive the optimized background regimen plus subcutaneous enfuvirtide or the optimized background regimen alone. At week 24 , the mean reductions in viral load in these patients with relatively advanced and treatment-resistant disease were significantly greater among enfuvirtide recipients than among controls.

The most common adverse events in all studies of subcutaneous enfuvirtide have been injection-site reactions, which are typically mild but occur in the majority of patients. These reactions usually result in pruritic subcutaneous nodules, although larger painful inflammatory masses are occasionally observed. In the phase 3 trials, ${ }^{84,85}$ self-administration of enfuvirtide was generally successful; approximately 3 percent of the patients discontinued treatment because of local reactions. A complex process of synthesis is required to produce enfuvirtide, but methods are being streamlined, and the drug has recently received approval from the Food and Drug Administration.

T-1249

The second peptide inhibitor of fusion that is now in development, T-1249, binds to a region partially overlapping with the region to which enfuvirtide binds but extending into a "deep-pocket" region of HR1 that is important for the formation of the sixhelix structure required for fusion. ${ }^{86} \mathrm{~T}-1249$ has been studied in a 14-day phase 1-2 trial involving 115 HIV-1-infected subjects. Subjects received $\mathrm{T}-1249$ alone at a total daily dose ranging from 6.25 to $200 \mathrm{mg}$, with some groups receiving oncedaily injections and others twice-daily injections. ${ }^{87}$ The largest median declines in plasma HIV-1 RNA levels (2.0 $\log _{10}$ copies per milliliter) were observed in subjects receiving 150 to $200 \mathrm{mg}$ once daily. Three serious adverse events thought to be related to T-1249 were observed.

\section{RESISTANCE TO ENFUVIRTIDE AND T-1249}

Analyses of HIV-1 from patients in the middle-dose groups of the original phase 1 trial of enfuvirtide demonstrated a rapid evolution of changes in the HR1 coding region, which correlated with resistance to the drug. ${ }^{88}$ The mutations cluster around a specific gp41 region, ${ }^{89,90}$ supporting the putative 
mechanism of action of enfuvirtide. Two amino acid changes in this region may lead to decreases by a factor of 100 in susceptibility. Most variants that are resistant to enfuvirtide maintain susceptibility to $\mathrm{T}-1249$ in vitro. ${ }^{81}$ Viruses containing mutations that confer resistance to enfuvirtide may have disadvantages of replication capacity (decreased "viral fitness") in the absence of selection pressure from the drug, as compared with wild-type virus. ${ }^{91}$ Recently, antiviral activity of T-1249 was demonstrated in subjects with prolonged previous exposure to enfuvirtide and documented enfuvirtide-resistant virus. 92

\section{FUTURE CONSIDERATIONS}

A new, diverse class of compounds designed or selected to inhibit the entry of HIV-1 into host cells is approaching clinical application. Early clinical experience with some of these compounds has been favorable, and toxic effects or drug-resistance patterns that overlap with those of currently available therapies have not been observed. Randomized clinical trials have recently demonstrated a benefit when a fusion inhibitor, enfuvirtide, is given as part of a salvage regimen for patients with drug-resistant HIV-1 who currently have limited therapeutic options.

As with all available antiretroviral agents, the clinical activity of viral-entry inhibitors will be limited by selection for drug-resistant viral variants unless the compounds can be used together with other effective drugs. Because dual-tropic virus or mixed populations of viruses may be present within the same host, CCR5 and CXCR4 inhibitors may have a greater likelihood of clinical effectiveness if they can be safely administered in combination. The availability of chemokine receptors modulates the susceptibility to membrane-fusion inhibitors in some in vitro assays ${ }^{90,93,94}$; however, there is no evidence thus far that this observation will have clinically significant implications. ${ }^{95}$ Several groups have demonstrated potent synergism between viral-entry inhibitors when various combinations of agents directed at the gp120-CD4 interaction (PRO 542), chemokine-receptor antagonists, and peptide-fusion inhibitors are evaluated in vitro. ${ }^{96-98}$

Observations regarding the range of susceptibility of different viral strains under different assay conditions and regarding the different degrees of synergism between agents that block viral entry may have similar pathogenetic explanations: factors that impede the initial steps toward entry, especially interactions with CCR 5 or CXCR4, may increase the window of opportunity for peptide inhibitors such as enfuvirtide to interfere with gp41-mediated fusion. ${ }^{94}$ These findings suggest that there may be good prospects for potent combinations of entry inhibitors, just as HIV-1 protease inhibitors or reverse-transcriptase inhibitors are administered together today.

Supported by grants (AI50410 and AI27767) to the Centers for AIDS Research at the University of North Carolina and the University of Alabama, Birmingham; by a grant (5MO1 RR00032-38) to the Pittman General Clinical Research Center at the University of Alabama, Birmingham; and by grants (AI41530-05 and AI32775-07) from the National Institutes of Health.

We are indebted to Michael S. Saag, M.D., for constant support and guidance over the years; and to Eric Hunter, Ph.D., for expert assistance with figures and mechanistic explanations.
REFERENCES

1. Barre-Sinoussi F, Chermann JC, Rey F, et al. Isolation of a T-lymphotropic retrovirus from a patient at risk for acquired immune deficiency syndrome (AIDS). Science 1983 220:868-71.

2. Gallo RC, Sarin PS, Gelmann EP, et al Isolation of human T-cell leukemia virus in acquired immune deficiency syndrome (AIDS). Science 1983;220:865-7.

3. Klatzmann $\mathrm{D}$, Champagne E, Chamaret $\mathrm{S}$, et al. T-lymphocyte T4 molecule behaves as the receptor for human retrovirus LAV. Nature 1984;312:767-8.

4. Dalgleish AG, Beverley PCL, Clapham $\mathrm{PR}$, et al. The CD4 (T4) antigen is an essential component of the receptor for the AIDS retrovirus. Nature 1984;312:763-7.

5. Earl PL, Doms RW, Moss B. Oligomeric structure of the human immunodeficiency virus type 1 envelope glycoprotein. Proc Natl Acad Sci U S A 1990;87:648-52
6. Weiss CD, Levy JA, White JM. Oligomeric organization of gp120 on infectious human immunodeficiency virus type 1 particles. J Virol 1990;64:5674-7.

7. Wyatt R, Sullivan N, Thali M, et al. Functional and immunologic characterization of human immunodeficiency virus type 1 envelope glycoproteins containing deletions of the major variable regions. J Virol 1993;67: 4557-65.

8. Moore JP, Sattentau QJ, Wyatt R, Sodroski J. Probing the structure of the human immunodeficiency virus surface glycoprotein gp120 with a panel of monoclonal antibodies. J Virol 1994;68:469-84.

9. Peterson A, Seed B. Genetic analysis of monoclonal antibody and HIV binding sites on the human lymphocyte antigen CD4. Cell 1988;54:65-72.

10. Lasky LA, Nakamura G, Smith DH, et al. Delineation of a region of the human immu- nodeficiency virus type 1 gp120 glycoprotein critical for interaction with the CD4 receptor. Cell 1987;50:975-85.

11. Kowalski M, Potz J, Basiripour L, et al. Functional regions of the envelope glycoprotein of human immunodeficiency virus type 1 . Science 1987;237:1351-5.

12. Skinner MA, Langlois AJ, McDanal CB, McDougal JS, Bolognesi DP, Matthews TJ. Neutralizing antibodies to an immunodominant envelope sequence do not prevent gp120 binding to CD4. J Virol 1988;62: 4195-200.

13. Freed EO, Myers DJ, Risser R. Identification of the principal neutralizing determinant of human immunodeficiency virus type 1 as a fusion domain. J Virol 1991;65: 190-4.

14. Cocchi F, DeVico AL, Garzino-Demo A, Arya SK, Gallo RC, Lusso P. Identification of RANTES, MIP-1 alpha, and MIP-1 beta as 
the major HIV-suppressive factors produced by CD8+ T cells. Science 1995;270:1811-5. 15. Feng Y, Broder CC, Kennedy PE, Berger EA. HIV-1 entry cofactor: functional cDNA cloning of a seven-transmembrane, $\mathrm{G}$ protein-coupled receptor. Science 1996;272: 872-7.

16. Dragic T, Litwin V, Allaway GP, et al HIV-1 entry into CD4+ cells is mediated by the chemokine receptor CC-CKR-5. Nature 1996;381:667-73.

17. Deng H, Liu R, Ellmeier W, et al. Identification of a major co-receptor for primary isolates of HIV-1. Nature 1996;381:661-6. 18. Hoxie JA, LaBranche CC, Endres MJ, et al. CD4-independent utilization of the CXCR4 chemokine receptor by HIV-1 and HIV-2. J Reprod Immunol 1998;41:197-211. 19. Wyatt R, SodroskiJ. The HIV-1 envelope glycoproteins: fusogens, antigens, and immunogens. Science 1998;280:1884-8.

20. Koot M, Keet IP, Vos AH, etal. Prognostic value of HIV-1 syncytium-inducing phenotype for rate of $\mathrm{CD} 4+$ cell depletion and progression to AIDS. Ann Intern Med 1993, 118:681-8.

21. Richman DD, Bozzette SA. The impact of the syncytium-inducing phenotype of human immunodeficiency virus on disease progression. J Infect Dis 1994;169:968-74.

22. Singh A, Collman RG. Heterogeneous spectrum of coreceptor usage among variants within a dualtropic human immunodeficiency virus type 1 primary-isolate quasispecies. J Virol 2000;74:10229-35.

23. Choe H, Farzan M, Sun Y, et al. The beta-chemokine receptors CCR3 and CCR5 facilitate infection by primary HIV-1 isolates. Cell 1996;85:1135-48.

24. Cocchi F, DeVico AL, Garzino-Demo A Cara A, Gallo RC, Lusso P. The V3 domain of the HIV-1 gp120 envelope glycoprotein is critical for chemokine-mediated blockade of infection. Nat Med 1996;2:1244-7.

25. Clapham PR, McNight A. Cell surface receptors, virus entry and tropism of primate lentiviruses. J Gen Virol 2002;83:1809-29.

26. Liu R, Paxton WA, Choe S, et al. Homozygous defect in HIV-1 coreceptor accounts for resistance of some multiply-exposed individuals to HIV-1 infection. Cell 1996;86:367-77. 27. Dean M, Carrington M, Winkler C, et al Genetic restriction of HIV-1 infection and progression to AIDS by a deletion allele of the CKR5 structural gene. Science 1996;273: 1856-62. [Erratum, Science 1996;274:1069. 28. Michael NL, Nelson JA, KewalRamani VN, et al. Exclusive and persistent use of the entry coreceptor CXCR 4 by human immunodeficiency virus type 1 from a subject homozygous for CCR5 delta32. J Virol 1998; 72:6040-7.

29. Gallaher WR, Ball JM, Garry RF, Griffin MC, Montelaro RC. A general model of the transmembrane proteins of HIV and other retroviruses. AIDS Res Hum Retroviruses 1989;5:431-40.

30. Delwart EL, Mosialos G, Gilmore T. Retroviral envelope glycoproteins contain a "leu- cine zipper"-like repeat. AIDS Res Hum Retroviruses 1990;6:703-6.

31. Dubay JW, Roberts SJ, Brody B, Hunte E. Mutations in the leucine zipper of the human immunodeficiency virus type 1 transmembrane glycoprotein affect fusion and infectivity. J Virol 1992;66:4748-56.

32. Carr C, Kim PS. A spring-loaded mechanism for the conformational change of influenza hemagglutinin. Cell 1993;73:823-32. 33. Chen $\mathrm{CH}$, Matthews TJ, McDanal CB, Bolognesi DP, Greenberg ML. A molecular clasp in the human immunodeficiency virus (HIV) type $1 \mathrm{TM}$ protein determines the antiHIV activity of gp41 derivatives: implication for viral fusion. J Virol 1995;69:3771-7.

34. Fisher RA, Bertonis JM, Meier W, et al. HIV infection is blocked in vitro by recombinant soluble CD4. Nature 1988;331:76-8.

35. Hussey RE, Richardson NE, Kowalski M, et al. A soluble CD4 protein selectively inhibits HIV replication and syncytium formation. Nature 1988;331:78-81.

36. Schooley RT, Merigan TC, Gaut P, et al. Recombinant soluble CD4 therapy in patients with the acquired immunodeficiency syndrome (AIDS) and AIDS-related complex: a phase I-II escalating dosage trial. Ann Intern Med 1990;112:247-53.

37. Schacker T, Collier AC, Coombs R, et al. Phase I study of high-dose, intravenous rsCD4 in subjects with advanced HIV-1 infection. J Acquir Immune Defic Syndr Hum Retrovirol 1995;9:145-52.

38. O'Brien WA, Chen IS, Ho DD, Daar ES Mapping genetic determinants for human immunodeficiency virus type 1 resistance to soluble CD4. J Virol 1992;66:3125-30.

39. Moore JP, McKeating JA, Huang YX, Ashkenazi A, Ho DD. Virions of primary human immunodeficiency virus type 1 isolate resistant to soluble $\mathrm{CD} 4$ (sCD4) neutralization differ in $\mathrm{SCD} 4$ binding and glycoprotein gp120 retention from sCD4-sensitive isolates. JVirol 1992;66:235-43.

40. Meng T-C, Fischl MA, Cheeseman SH, et al. Combination therapy with recombinant human soluble CD4-immunoglobulin $\mathrm{G}$ and zidovudine in patients with HIV infection: a phase I study. J Acquir Immune Defic Syndr Hum Retrovirol 1995;8:152-60.

41. Trkola A, Pomales AB, Yuan $\mathrm{H}$, et al. Cross-clade neutralization of primary isolates of human immunodeficiency virus type 1 by human monoclonal antibodies and tetrameric CD4-IgG. J Virol 1995;69:6609-17.

42. Jacobson JM, Lowy I, Fletcher CV, et al. Single-dose safety, pharmacology, and antiviral activity of the human immunodeficiency virus (HIV) type 1 entry inhibitor PRO 542 in HIV-infected adults. J Infect Dis 2000 182:326-9.

43. Shearer WT, Israel RJ, Starr S, et al. Recombinant CD4-IgG2 in human immunodeficiency virus type 1 -infected children: phase 1/2 study. J Infect Dis 2000;182:1774-9. 44. Shearer MH, Timanus DK, Benton PA, Lee DR, Kennedy RC. Cross-clade inhibition of human immunodeficiency virus type 1 primary isolates by monoclonal anti-CD4. J Infect Dis 1998;177:1727-9.

45. Moreland LW, Bucy RP, Koopman WJ. Regeneration of T cells after chemotherapy. N Engl J Med 1995;332:1651-2.

46. Wofsy D. Treatment of murine lupus with anti-CD4 monoclonal antibodies. Immunol Ser 1993;59:221-36.

47. Kuritzkes DR, Jacobson JM, Powderly WG, et al. Safety and preliminary anti-HIV activity of an anti-CD4 mAb (TNX-355; formerly Hu5A8) in HIV-infected patients. In: Programs and abstracts of the 10th Conference on Retroviruses and Opportunistic Infections, Boston, February 10-14, 2003. Alexandria, Va.: Foundation for Retrovirology and Human Health, 2003:62. abstract.

48. Lin P-F, Guo K, Fridell R, Ho H-T, Yamanaka G, Colonno R. Identification and characterization of a novel inhibitor of HIV-1 entry. II. Mechanism of action. In: Programs and abstracts of the Ninth Conference on Retroviruses and Opportunistic Infections, Seattle, February 24-28, 2002. Alexandria, Va.: Foundation for Retrovirology and $\mathrm{Hu}-$ man Health, 2001:56. abstract.

49. Lin P-F, Gong YF, Rose B, et al. Generation and characterization of HIV-1 variants resistant to BMS 806, a novel HIV-1 entry inhibitor. Antiviral Ther 2002;7:Suppl 1:S8 abstract.

50. Mitsuya H, Looney DJ, Kuno S, Ueno R, Wong-Staal F, Broder S. Dextran sulfate suppression of viruses in the HIV family: inhibition of virion binding to $\mathrm{CD} 4+$ cells. Science 1988;240:646-9.

51. Moulard M, Lortat-Jacob H, Mondor I, et al. Selective interactions of polyanions with basic surfaces on human immunodeficiency virus type 1 gp120. J Virol 2000;74:1948-60. 52. Este JA, Schols D, De Vreese K, et al. Development of resistance of human immunodeficiency virus type 1 to dextran sulfate associated with the emergence of specific mutations in the envelope gp120 glycoprotein. Mol Pharmacol 1997;52:98-104.

53. Meylan P, Kornbluth RS, Zbinden I, Richman DD. Influence of host cell type and V3 loop of the surface glycoprotein on susceptibility of human immunodeficiency virus type 1 to polyanion compounds. Antimicrob Agents Chemother 1994;38:2910-6.

54. Flexner C, Barditch-Crovo PA, Kornhauser DM, et al. Pharmacokinetics, toxicity, and activity of intravenous dextran sulfate in human immunodeficiency infection. Antimicrob Agents Chemother 1991;35:2544-50. 55. Rusconi S, Moonis M, Merrill DP, et al. Naphthalene sulfonate polymers with CD4blocking and anti-human immunodeficiency virus type 1 activities. Antimicrob Agents Chemother 1996;40:234-6.

56. Van Damme L, Wright A, Depraetere K, et al. A phase I study of a novel potential intravaginal microbicide, PRO 2000, in healthy sexually inactive women. Sex Transm Infect 2000;76:126-30.

57. Mori T, Boyd MR. Cyanovirin-N, a potent human immunodeficiency virus-inactivating 
protein, blocks both CD4-dependent and CD4-independent binding of soluble gp120 (sgp120) to target cells, inhibits sCD4 induced binding of sgp120 to cell-associated CXCR4, and dissociates bound sgp120 from target cells. Antimicrob Agents Chemother 2001;45:664-72.

58. Dragic T, Trkola A, Thompson DA, et al A binding pocket for a small molecule inhibitor of HIV-1 entry within the transmembrane helices of CCR5. Proc Natl Acad Sci U S A 2000;97:5639-44.

59. Rusconi S, La Seta Catamancio S, Citterio $\mathrm{P}$, et al. Combination of CCR 5 and CXCR inhibitors in therapy of human immunodeficiency virus type 1 infection: in vitro studies of mixed virus infections. JVirol 2000 74:9328-32.

60. Simmons G, Clapham PR, Picard L. Po tent inhibition of HIV-1 infectivity in macrophages and lymphocytes by a novel CCR5 antagonist. Science 1997;276:276-9.

61. Cairns JS, D'Souza MP. Chemokines and HIV-1 second receptors: the therapeutic connection. Nat Med 1998;4:563-8.

62. Mosier DE, Picchio GR, Gulizia RJ, et al. Highly potent RANTES analogues eithe prevent CCR5-using human immunodeficiency virus type 1 infection in vivo or rapidly select for CXCR4-using variants. J Viro 1999;73:3544-50.

63. Strizki JM, Xu S, Wagner NE, et al SCH-C (SCH 351125), an orally bioavailable, small molecule antagonist of the chemokine receptor CCR 5 , is a potent inhibitor of HIV-1 infection in vitro and in vivo. Proc Natl Acad Sci U S A 2001;98:12718-23.

64. Reyes G. Development of CCR 5 antagonists as a new class of anti-HIV therapeutic. In: Programs and abstracts of the Eighth Conference on Retroviruses and Opportunistic Infections, Chicago, February 4-8, 2001. Alexandria, Va.: Foundation for Retrovirology and Human Health, 2001:285. abstract. 65. Trkola A, Ketas TJ, Nagashima KA, et al. Potent broad-spectrum inhibition of human immunodeficiency virus type 1 by the CCR monoclonal antibody PRO 140. J Virol 2001; 75:579-88.

66. Reynes J, Rouzier R, Kanouni T, et al. Safety and antiviral effects of a CCR 5 receptor antagonist in HIV-1 infected subjects. In Programs and abstracts of the Ninth Conference on Retroviruses and Opportunistic Infections, Seattle, February 24-28, 2002. Alexandria, Va.: Foundation for Retrovirology and Human Health, 2002:53. abstract. 67. Trkola A, Kuhmann SE, Strizki JM, et al. HIV-1 escape from a small molecule, CCR5specific entry inhibitor does not involve CXCR4 use. Proc Natl Acad Sci U S A 2002; 99:395-400.

68. Nagasawa T, Hirota S, Tachibana K, et al. Defects of B-cell lymphopoiesis and bonemarrow myelopoiesis in mice lacking the CXC chemokine PBSF/SDF-1. Nature 1996; 382:635-8.

69. Doranz BJ, Filion LG, Diaz-Mitoma F, et al. Safe use of the CXCR4 inhibitor ALX40-4C in humans. AIDS Res Hum Retroviruses 2001; $17: 475-86$

70. Donzella GA, Schols D, Lin SW. AMD3100, a small molecule inhibitor of HIV-1 entry via the CXCR 4 co-receptor. Nat Med 1998;4:72-7.

71. Hendrix CW, Flexner C, MacFarland RT et al. Pharmacokinetics and safety of AMD3100 , a novel antagonist of the CXCR 4 chemokine receptor, in human volunteers. Antimicrob Agents Chemother 2000;44: 1667-73.

72. Schols D, Claes S, De Clercq E, et al AMD-3100, a CXCR4 antagonist, reduced HIV viral load and X4 levels in humans. In Programs and abstracts of the Ninth Conference on Retroviruses and Opportunistic Infections, Seattle, February 24-28, 2002 Alexandria, Va.: Foundation for Retrovirology and Human Health, 2002:53. abstract.

73. de Vreese K, Kofler-Mongold V, Leutgeb $\mathrm{C}$, et al. The molecular target of bicyclams, potent inhibitors of human immunodeficiency virus replication. J Virol 1996;70:689-

74. Zhang L, Yu W, He T, et al. Contribution of human alpha-defensin 1,2 , and 3 to the anti-HIV-1 activity of CD8 antiviral factor. Science 2002;298:995-1000.

75. Eckert DM, Malashkevich VN, Hong LH, Carr PA, Kim PS. Inhibiting HIV-1 entry: discovery of D-peptide inhibitors that targe the gp41 coiled-coil pocket. Cell 1999;99: 103-15.

76. Ferrer M, Kapoor TM, Strassmaier T, et al. Selection of gp41-mediated HIV-1 cell entry inhibitors from biased combinatoria libraries of non-natural binding elements. Nat Struct Biol 1999;6:953-60.

77. Judice JK, Tom JY, Huang W, et al. Inhibition of HIV type 1 infectivity by constrained alpha-helical peptides: implications for the viral fusion mechanism. Proc Natl Acad Sci U S A 1997;94:13426-30.

78. Wild C, Greenwell T, Matthews T. A synthetic peptide from HIV-1 gp41 is a poten inhibitor of virus-mediated cell-cell fusion. AIDS Res Hum Retroviruses 1993;9:1051-3. 79. Kilby JM, Hopkins S, Venetta TM, et al. Potent suppression of HIV-1 replication in humans by T-20, a peptide inhibitor of gp 41 mediated virus entry. Nat Med 1998:4:1302 7.

80. Kilby JM, Lalezari JP, Eron JJ, et al. The safety, plasma pharmacokinetics, and antiviral activity of subcutaneous enfuvirtide (T-20), a peptide inhibitor of gp41-mediated virus fusion, in HIV-infected adults. AIDS Res Hum Retroviruses 2002;18:685-93. [Erratum, AIDS Res Hum Retroviruses 2003;19:83.]

81. Greenberg M, Sista P, Miralles G, et al. Enfuvirtide (T-20) and T-1249 resistance: observations from phase II clinical trials of enfuvirtide in combination with oral antiretrovirals and a phase I/II dose-ranging monotherapy trial of T-1249. Antiviral Ther 2002; 7:Suppl:S140. abstract.

82. Lalezari JP, Eron JJ, Carlson M, et al.
A phase II clinical study of the long-term safety and antiviral activity of enfuvirtidebased antiretroviral therapy. AIDS 2003;17 691-8.

83. Lalezari J, Drucker J, Demasi R, Hopkins S, Salgo M. A controlled phase II trial assessing three doses of T-20 in combination with abacavir, amprenavir, low dose ritonavir, and efavirenz in non-nucleoside naive, protease inhibitor-experienced, HIV-1infected adults: In: Programs and abstracts of the Eighth Conference on Retroviruses and Opportunistic Infections, Chicago, February 4-8, 2001. Alexandria, Va.: Foundation for Retrovirology and Human Health, 2001:277. abstract.

84. Lalezari JP, Henry K, O'Hearn M, et al. Enfuvirtide, an HIV-1 fusion inhibitor, for drug-resistant HIV infection in North and South America. N Engl J Med 2003;348: 2175-85.

85. Lazzarin A, Clotet B, Cooper D, et al. Efficacy of enfuvirtide in patients infected with drug-resistant HIV-1 in Europe and Australa. N Engl J Med 2003;348:2186-95.

86. Greenberg M, Davison D, Jin L, et al. In vitro antiviral activity of T-1249, a second generation fusion inhibitor. Antiviral Ther 2002;7:Suppl:S14. abstract.

87. Eron J, Merigan T, Kilby M, etal. A 14-day assessment of the safety, pharmacokinetics, and antiviral activity of T-1249, a peptide inhibitor of membrane fusion. In: Programs and abstracts of the Eighth Conference on Retroviruses and Opportunistic Infections, Chicago, February 4-8, 2001. Alexandria, Va.: Foundation for Retrovirology and $\mathrm{Hu}-$ man Health, 2001:47. abstract.

88. Wei X, Decker JM, Liu H, et al. Emergence of resistant human immunodeficiency virus type 1 in patients receiving fusion inhibitor (T-20) monotherapy. Antimicrob Agents Chemother 2002;46:1896-905.

89. Rimsky LT, Shugars DC, Matthews TJ. Determinants of human immunodeficiency virus type 1 resistance to gp41-derived inhibitory peptides. J Virol 1998;72:986-93.

90. Derdeyn CA, Decker JM, Sfakianos JN, et al. Sensitivity of human immunodeficiency virus type 1 to the fusion inhibitor T-20 is modulated by coreceptor specificity defined by the V3 loop of gp120. J Virol 2000;74: 8358-67.

91. Lu J, Sista P, Cammack N, Kurtizkes D. Fitness of HIV-1 clinical isolates resistant to T-20 (enfuvirtide). Antiviral Ther 2002;7: Suppl:S74. abstract

92. Miralles G, Lalezari J, Bellos N, et al. T-1249 demonstrates potent antiviral activity over 10-day dosing in most patients who have failed a regimen containing enfuvirtide: planned interim analysis of T1249-102, a phase I/II study. In: Programs and abstracts of the 10th Conference on Retroviruses and Opportunistic Infections, Boston, February 10-14, 2003. Alexandria, Va.: Foundation for Retrovirology and Human Health, 2003:63. abstract.

93. Derdeyn CA, Decker JM, Sfakianos JN, 
et al. Sensitivity of human immunodeficiency virus type 1 to fusion inhibitors targeted to the gp41 first heptad repeat involves dis tinct regions of gp41 and is consistently modulated by gp120 interactions with the coreceptor. J Virol 2001;75:8605-14.

94. Reeves JD, Gallo SA, Ahmad N, et al. Sensitivity of HIV-1 to entry inhibitors correlates with envelope/coreceptor affinity, receptor density, and fusion kinetics. Proc Natl Acad Sci U S A 2002;99:16249-54.

95. Greenberg ML, McDanal CB, StanfieldOakley SA, et al. Virus sensitivity to T-20 and $\mathrm{T}-1249$ is independent of coreceptor usage. In: Programs and abstracts of the Eighth
Conference on Retroviruses and Opportunistic Infections, Chicago, February 4-8, 2001. Alexandria, Va.: Foundation for Retrovirology and Human Health, 2001:184. abstract.

96. Tremblay C, Kollman C, Giguel F, Chou TC, Hirsch MS. Strong in vitro synergy observed between the fusion inhibitor T-20 and a CXCR4 blocker, AMD3100. In: Programs and abstracts of the Seventh Conference on Retroviruses and Opportunistic Infections, San Francisco, January 30-February 4, 2000. Alexandria, Va.: Foundation for Retrovirology and Human Health, 2001:170. abstract.

97. Nagashima KA, Thompson DA, Rosen- field SI, Maddon PJ, Dragic T, Olson WC. Human immunodeficiency virus type 1 entr inhibitors PRO 542 and T-20 are potently synergistic in blocking virus-cell and cellcell fusion. J Infect Dis 2001;183:1121-5.

98. Tremblay CL, Giguel F, Kollmann C, et al. Anti-human immunodeficiency virus interactions of SCH-C (SCH 351125), a CCR5 antagonist, with other antiretroviral agents in vitro. Antimicrob Agents Chemother 2002;46:1336-9.

Copyright (c) 2003 Massachusetts Medical Society.

FULL TEXT OF ALL JOURNAL ARTICLES ON THE WORLD WIDE WEB

Access to the complete text of the Journal on the Internet is free to all subscribers. To use this Web site, subscribers should go to the Journal's home page (http://www.nejm.org) and register by entering their names and subscriber numbers as they appear on their mailing labels. After this one-time registration, subscribers can use their passwords to log on for electronic access to the entire Journal from any computer that is connected to the Internet. Features include a library of all issues since January 1993 and abstracts since January 1975, a full-text search capacity, and a personal archive for saving articles and search results of interest. All articles can be printed in a format that is virtually identical to that of the typeset pages. Beginning six months after publication the full text of all original articles and special articles is available free to nonsubscribers who have completed a brief registration. 